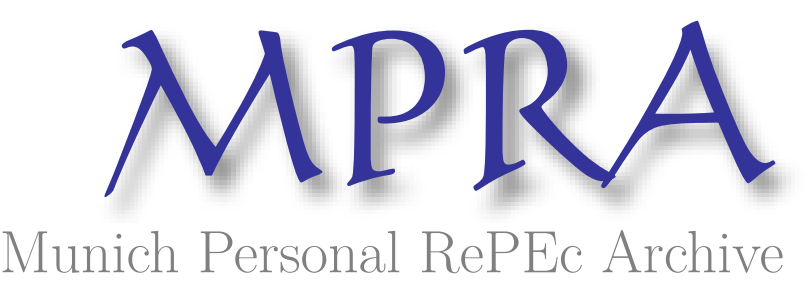

\title{
Inflation dynamics in pre and post deregulation era in Ghana: Do petroleum prices have any influence?
}

Addae, Edna and Ackah, Ishmael

7 March 2017

Online at https://mpra.ub.uni-muenchen.de/77496/

MPRA Paper No. 77496, posted 16 Mar 2017 06:26 UTC 


\title{
Inflation dynamics in pre and post deregulation era in Ghana: Do petroleum prices have any influence?
}

\author{
Edna Addae \\ Department of Chemistry, \\ University of Ghana \\ ednadd@ymail.com
}

Ishmael Ackah

Africa Centre for Energy Energy

Ackish85@yahoo.com 
Abstract

The study looks at the impact of price of petroleum prices on inflation in the Ghanaian economy in the pre and post deregulation era and associated direction of causality as well as the extent of pass through of high international petroleum products price to the domestic retail market. An ARDL model was applied on time series monthly data of various petroleum fuel prices as well as exchange rate.A pass-through formula use by Baig et al, (2007) was also applied.

The results reveal that changes in LPG, Kerosene and premium prices have marginal impact on inflation. The pass through analysis revealed Ghana has not pass through more than $50 \%$ of increase price of international or import petroleum product of gasoline, kerosene and LPG to the ordinary consumers in the period of the study and this was lower in the post deregulation than pre deregulation. The study therefore recommends full deregulation to continue since it favours lower pass through of fuel price increase in the world market to ordinary consumers whiles may consider gasoline and premium price increase at the expense of kerosene and liquefied petroleum gas price if inflation is to be shielded from fuel price increase.

Key Words: Inflation, Deregulation, Petroleum Prices, Ghana

\section{Background.}

Energy is considered as one of the basic fundamental chief corner stone for stimulating economic growth, as it is demanded by all sectors of an economy (Birol, 2010; CERA, 2013). In these modern times, every economic agent is highly reliant on continuous energy supply for daily activities of production and consumption. Most developing countries such as Ghana, Togo. 
Singapore etc. are net importers of oil and in such countries, prices of petroleum-products are mostly fixed by the government (via directly control prices of imports and distribution of petroleum products, subsidisation, as well as domestic sale prices), which is a common occurrence (Hossain, 2003).

It has been observed that, there is an enormous effect petroleum product price hikes on developing countries economy. As fuel price increases triggers the upward adjustment of all items in the economy including transportation, basic commodities and cost of production. This has compelled governments in most developing countries to introduce fuel subsidies to regulate its impact on the economy. Petroleum products subsidization in countries that are developing with rising economies is a common occurrence and Ghana is not an exception. Subsidising fuel and other petroleum products by and large emerge out of a craving to shield buyers, particularly poor family unit and frequently unpredictable cost of fuels for their daily usage as it inspires more consumption. In a way, the greater part of the fuel subsidies do go to higher income earners who have the tendency to use more fuel (Arze et al, 2012).

Ojo and Adebusuyi (1996) posit that depreciation of the cedi, huge taxes, high inflation rate and other country-exogenous factors determine a change in the prices of petroleum products. Ghana's initial endeavour in liberalizing fuel prices happened in mid- 2001 with the setting up of automatic price setting mechanism, which connected internal prices to global ones. It was later deserted towards the end of the next year, compelling petroleum product prices to be under government control once more. It was later again reinstated in mid- 2003, magnifying fuel prices as a result. Notwithstanding, the formula was abandoned again as a result of pressures from the general public (Acheampong and Ackah, 2015). Fuel subsidies rose to 2.2 percent of GDP in 2004 (UNICEF, 
2014). As subsidizing of petroleum products turned into a significant drain of resources of the public. A study by Coady et al, (2005) posits that fuel subsidies removal, by instigating an increase in prices, results in a negative impact on household welfare. This negatively significant effect is worst for the poorest households. Where these poor household's reduces their total consumption by about $2.1 \%$.

Conversely, petroleum products subsidies are both inefficient and inequitable (Clements, 288013; IMF, 2010; 2013; Parikh, 2010). These subsides did quite more harm than good to the Ghanaian economy as it increased government expenditure which exceeds government revenue, resulting in perennial budget deficits. The continuous increase in government deficits and its consequences on macroeconomic stability have triggered a debate on government continuous support in these areas and its sustainability. The government of Ghana and opinion of players and experts in the petroleum industry did believed that a proposed market liberalization would relief government from significant economic burdens and grant her the opportunity of diverting the rather burdensome subsidy payments on the petroleum products which she does carry to other needful sectors of the economy. The government of Ghana introduced the deregulation of the petroleum sector in June 2015 to reduce the huge debts that deprives the Oil Marketing Companies (OMC's) the needed capital for effective and sustainable business operations.

The reason that necessitates deregulation of the downstream petroleum sector on June 6, 2015 was that, in freeing the sector market pricing constraints, the forces of demand and supply within the market would invariably operate to regulate quantity delivered and prices that will prevail, as well as enhance healthy competition among firms and players of the industry (Doshi \& Corrigan, 2015). The government of Ghana and player in the petroleum industry believe that proposed market 
liberalization would relief government from significant economic burdens and grant her the opportunity of diverting the rather burdensome subsidy payments on the petroleum products which she does carry to other needful sectors of the economy. The government of Ghana introduced the deregulation of the petroleum sector in 2015 to reduce the huge debts that deprives the Oil Marketing Companies (OMC's) the needed capital for effective and sustainable business operations (Khalid \& Iddrisu, 2015).

Even though a plethora of studies of oil-price increase/fluctuation impact on economic performance exist, however, studies on the impact of oil/petroleum product price deregulation in an economy was found to be few in literature, especially for developing nations. For instance, Idris (2014) found a negative impact of oil subsidy removal on small scale businesses in Nigeria. On the other hand, Maduka et al. (2015) reveals that, variation in oil price from deregulation positively affects output (GDP) and inflation for Nigeria, a net-oil exporter.

The impact of oil-price deregulation, and hence complete subsidy removal could have a different outcome for Ghana, net importer of oil. The deregulation of petroleum-product prices, and hence the removal of fuel subsidy in Ghana implies that, people will pay the actual price and this will eliminate distortions in the market, and increase efficiency in resource allocation for healthy growth of the nation.

On the contrary, this can impact the Ghanaian economy adversely as there are no better/close alternative energy products to substitute crude-oil or petroleum products, and thus a highly inelastic demand nature exists, as it is a crucial factor for consumption and production sectors and hence economic growth. The removal of the subsidy may affect standards of living via exploitation from the transport sectors in Ghana, as transport prices are sticky downwards, and will adversely 
affect almost all spheres of the household sector as well as the production sectors of the economy negatively. Hence, an inflationary effect is highly expected, increasing poverty levels, high cost of production and unemployment, social unrest issue.

The final implementation of oil price deregulation exercise in Ghana is a new phenomenon that affects various sectors of the macro and micro economy. But the effect of the deregulation exercise on macroeconomic indicators specifically inflation and output, has not yet been examined in literature for Ghana, hence a knowledge gap which this study seeks to fill. In addition, the international oil price pass through effect on local prices will be examined in the pre- and postderegulation eras.

\subsection{Literature Review}

\subsubsection{The Concept of Deregulation and Subsidy}

Deregulation is when government continuously takes away or remove regulations imposed on the economy in the aim of relieving it. Again it is when restriction in a particularly industry is 
withdrawn to improve operation of business activities and competition. It is the removing of impediments to trade; control of the movement of goods and services, thereby allowing free flow interplay of the forces of demand and supply in the determination of the price of commodities and wages of services rendered (Ojo, and Adebusuyi, 1996). From the dictionary perspective, the Oxford Advanced Learners' dictionary (2005) defined deregulation as the act of freeing a trade or business outside of the rules and controls. Deregulation therefore occurs when the government seeks to allow more competition in an industry that condoles near monopolies hence, a general word that refers to the practice of transforming an economy to one that is open to all interested players and is usually driven by market forces. Akinwumi et a (2005), defines deregulation as the removal of government interference in the running of a system. This means that government rules and regulations governing the operations of the system are relaxed or held constant in order for the system to decide its own optimum level through the forces of supply and demand (Ekundayo, and Ajayi, 2008).Hence deregulation of downstream petroleum products prices means market power of supply and demand are allowed to primarily determine prices of petroleum products.

Since trying to define subsidy may be too elusive, it is more appropriate to consider characteristics of subsidy definitions. Firstly, occurrence of subsidy results from direct or potential expenditure of government through budget allocation to producers and consumers. Example is provision of guarantees. Again, certain public goods and service such as university education, public transport or food stamps may be delivered or produced at lower or below market price or free.Such transfers also involve expenses for the government, with the difference being that beneficiaries receive inkind contributions as opposed to funds they can freely dispose of. 
Furthermore, transfer of pregulatory policies within groups may be considered as subsidies. Schluep and de Gorter (2000) substantiated that pooling of revenues and price discrimination offered to producers that are implicitly financed by domestic consumers can results from regulatory policy of border protection. One such agreement that have clearly define the concept of subsidy is the World Trade Organisation (WTO) Agreement on Subsidies and Countervailing Measures (ACMS) which defined subsidy as financial contribution by a government or public body that confers a benefit.

\subsubsection{Deregulation, Subsidy and petroleum products prices}

As argued by Ajayi (1992), Akindele (2011) asserts that there has been differing opinion on the removal and deregulation of petroleum subsidy. Some researchers like Akinola (2011) are of the view that the removal of subsidy is healthy for economic growth and development, based on the premise that remunerating the actual cost reveals the true cost of petroleum-energy consumption which leads to a greater level of efficiency.

Okafor (2012) posit that when downstream oil sector is and deregulated and liberalized, it can end perennial fuel scarcity, reduce incidents of petroleum products smuggling, augur efficiency, attracts foreign investment and maintain sustainable fuel supply across the polity. They also argued that petroleum products in Nigeria were the lowest in the world and with deregulation, the government would be able to channel funds to other sectors of the economy. He again posit that deregulation will allow oil sector stakeholders, major and independent marketers, to import and market oil products and thereby break the monopoly enjoy by Nigerian National Petroleum Corporation (NNPC) on fuel supply and hence saved the country 
In reviewing empirical studies on deregulation and subsidy of petroleum product prices on macroeconomic indicators, Akindele (2011) asserts that there has been differing opinion on the removal and deregulation of petroleum subsidy. Some studies like Akinola (2011) are of the view that the removal of subsidy is healthy for economic growth and development, based on the premise that remunerating the actual cost reveals the true cost of petroleum-energy consumption which leads to a greater level of efficiency.

However, such exercise can affect macroeconomic variables like inflation, unemployment, economic growth, etc., in the opposite way. Hence, there are highly associated cost with petrol subsidy removal and its price deregulation. Below are some empirical findings on the related subject of interest.

Arenze (2011) examined the economic impact of price instability of oil products in Nigeria from 1978 to 2007 using simple regression analysis. The Author find out that, the inflation rate increased as petroleum product price increases which were observed most in period 1990-2007 where price increase occurred massively. The research concludes significant impact of inflation by price of petrol within that period.

In relation to the impact of deregulation on inflation, Bobai (2012) in his study, the impact of increase of petroleum prices on inflation in the Nigerian economy for the periods 1990 to 2011, by the OLS technique concludes that a positive relationship exist between Automotive Gas Oil (AGO), Premium Motor Spirit (PMS), and inflation, with PMS having the more significant impact 
on inflation. There was a negative relationship between inflation and Dual Purpose Kerosene (DPK). In general, an increase in petroleum prices thus increases inflation rate.

Also Awuse (2008) in his thesis determinants of petroleum prices in Ghana, 1985-2005 concluded that deregulation is supported by industry experts, mostly from the National Petroleum Authority (NPA), Tema Oil Refinery (TOR), Oil Marketing Companies (OMCs), Ministries, Departments and Agencies and not general consumers who rather prefers regulation of petroleum prices.

In relation to the impact of deregulation on economic output, Monday (2013) assessed the influence of petroleum deregulation on growth of Nigeria's economy from 1980 to 2011, by applying Ordinary Least Square (OLS) technique. The study revealed an increase in petroleum product prices was not due to deregulation policies.

Maduka et al. (2015) evaluated the effect of the petroleum industry deregulation on Nigeria's economy from time periods 1981 to 2010 by using OLS methodology with such as prices of petroleum products (PPP), Total supply of petroleum (TSP) and petroleum consumption (CONSP) and economic growth - nominal GDP, inflation, exchange rate, gross capital formation and labour employed. The results revealed that in the long run period, all variables except labour employed impacted significant and positive on economic growth with labour impacting negatively and significantly on economic growth.

Sani (2013) in his study the effect of deregulation of downstream oil sector on four macroeconomic variables, namely; GDP, Inflation, Unemployment and Minimum wage in Nigeria used Vector 
Autoregressive (VAR) model on quarterly data over the period 1980q1 to 2012q4. The study reviewed that variation in GDP, Inflation and Unemployment has its major source from changes in oil price due to deregulation whilst these changes doesn't significantly cause variation in minimum wage. The paper also discovered that the impact of oil price changes on GDP and Inflation was positive but negative on Unemployment and Minimum wage in the short run which became positive in the long run. Finally the Granger causality test indicates there is no evidence of a causal relationship with Minimum wage and Unemployment but evidence of unidirectional causality running from Petroleum prices to GDP and from Inflation to Petroleum prices.

Danjuma (2012) examined the impact of increase of petroleum prices in the Nigerian economy applying the multiple regression analysis model of the OLS techniques to examine the relationship between the inflation rate and petroleum prices from 1990-2011 The results showed positive relationship exists between PMS, AGO and inflation with PMS impacting more on inflation, while negative relationship exists between inflation and DPK. However, the overall effect showed increase in petroleum product price increase the rate of inflation in Nigeria.

Nwosu (2009) in her work the impact of fuel price on inflation, which used the variance Autoregressive analysis model to assess the relative contribution of fuel price on inflation. The study used available quarterly data series spanning 1995 to 2008 . The study concludes that to reduce the impact of negative effect of oil-price shock, subsidy policy on price of fuel should be continued

Aretha et al (2015), studied Petroleum Products Prices and Inflationary Dynamics in Nigeria, using ordinary least square techniques on time series data of inflation and petroleum products prices from the period 1994-2012.The empirical results indicated there exists high positive 
relationship between the prices of PMS and AGO and inflation in Nigeria. Conclusion drawn was that, rises in petroleum products prices, especially PMS and AGO significantly impact inflation in Nigeria. They also recommend that Government should maintain subsidy on PMS the time being and rather focus on deregulating the downstream sector to attract private investment with the aim of encouraging local refining of petroleum products instead of importing them. This will in turn reduce domestic prices for petroleum products and consequently inflation.

In the case of how developing and emerging economies pass on increase in international oil and its products prices to domestic prices and consequently consumers, Baig et al (2007), reviewed recent developments in the pass-through of international to domestic petroleum product prices, in the different fuel pricing regimes, and in fuel subsidies in a range of emerging market and developing economies, Baig et al (2007) found limited price pass-through in many countries and the consequent increase in fuel subsidies and recommended making subsidies explicit; making pricing mechanisms more robust; combining reductions in subsidies with measures to protect the poorest; using the resulting savings well, and transparency and consultation.

Table 1 literature summary on deregulation, petroleum fuel price and inflation 



\begin{tabular}{|c|c|c|c|}
\hline Author & Country & Method & Findings \\
\hline Awuse (2008) & Ghana & $\begin{array}{l}\text { The petroleum Price } \\
\text { Asymmetry Model by } \\
\text { Borestain, Cameron } \\
\text { and Gilbert (BCG), } \\
1997 \text { cointegration } \\
\text { and error correction } \\
\text { mode }\end{array}$ & $\begin{array}{l}\text { Deregulation is } \\
\text { supported by industry } \\
\text { experts, mostly from } \\
\text { the National } \\
\text { Petroleum Authority } \\
\text { (NPA), Tema Oil } \\
\text { Refinery (TOR), Oil } \\
\text { Marketing } \\
\text { Companies (OMCs), } \\
\text { and and and a } \\
\text { Departments and } \\
\text { Agencies and not } \\
\text { general consumers } \\
\text { who rather prefer } \\
\text { petroleum prices. }\end{array}$ \\
\hline
\end{tabular}




\begin{tabular}{|c|c|c|c|}
\hline Baig et al & $\begin{array}{l}\text { 51Emerging and } \\
\text { developing countries } \\
\text { and G7 countries }\end{array}$ & Pass through formula & $\begin{array}{l}\text { limited price pass- } \\
\text { through in many } \\
\text { countries and the } \\
\text { consequent increase } \\
\text { in fuel subsidies }\end{array}$ \\
\hline Danjuma (2012) & Nigeria & OLS techniques & $\begin{array}{l}\text { The results showed } \\
\text { positive relationship } \\
\text { exists between PMS, } \\
\text { AGO and inflation } \\
\text { with PMS impacting } \\
\text { more on inflation, } \\
\text { while negative } \\
\text { relationship exists } \\
\text { between inflation and } \\
\text { DPK. }\end{array}$ \\
\hline
\end{tabular}




\begin{tabular}{|c|c|c|c|}
\hline Nwosu (2009) & & $\begin{array}{l}\text { The variance } \\
\text { Autoregressive } \\
\text { analysis model }\end{array}$ & $\begin{array}{l}\text { To reduce the impact } \\
\text { of negative effect of } \\
\text { oil-price shock, } \\
\text { subsidy policy on } \\
\text { price of fuel should be } \\
\text { continued. }\end{array}$ \\
\hline Eregha et al (2015) & Nigeria & OLS & $\begin{array}{l}\text { rises in petroleum } \\
\text { products prices, } \\
\text { especially PMS and } \\
\text { AGO significantly } \\
\text { impact inflation in } \\
\text { Nigeria }\end{array}$ \\
\hline Arenze (2011) & Nigeria & OLS & $\begin{array}{l}\text { inflation rate } \\
\text { increased } \\
\text { petroleum product } \\
\text { price increases which } \\
\text { was observed most in }\end{array}$ \\
\hline
\end{tabular}




\begin{tabular}{|c|c|c|c|}
\hline Bobai (2012) & Nigeria & OLS technique & $\begin{array}{l}\text { The results showed a } \\
\text { positive relationship } \\
\text { existing between } \\
\text { Premium Motor Spirit } \\
\text { (PMS), Automotive } \\
\text { Gas Oil (AGO) and } \\
\text { inflation and negative } \\
\text { for Dual Purpose } \\
\text { Kerosene (DPK); }\end{array}$ \\
\hline Monday (2013) & Nigeria & OLS technique & $\begin{array}{l}\text { The study revealed } \\
\text { deregulation policies } \\
\text { not the cause of an } \\
\text { increase in petroleum } \\
\text { product prices }\end{array}$ \\
\hline
\end{tabular}




\begin{tabular}{|c|c|c|c|}
\hline Maduka et al. (2015) & Nigeria & OLS technique & $\begin{array}{l}\text { The results revealed } \\
\text { that in the long run } \\
\text { period, all variables } \\
\text { except labour } \\
\text { employed and } \\
\text { positive } \\
\text { significant impact on } \\
\text { economic growth } \\
\text { with labour impacting } \\
\text { negatively and } \\
\text { significantly on } \\
\text { economic growth }\end{array}$ \\
\hline
\end{tabular}




\begin{tabular}{|c|c|c|c|}
\hline Sani (2013) & Nigeria & $\begin{array}{l}\text { Vector } \\
\text { Autoregressive } \\
\text { (VAR) model }\end{array}$ & $\begin{array}{l}\text { Variation in GDP, } \\
\text { Inflation and } \\
\text { Unemployment has } \\
\text { its major source from } \\
\text { changes in oil price } \\
\text { due to deregulation } \\
\text { whilst these changes } \\
\text { doesn't significantly } \\
\text { cause variation in } \\
\text { minimum wage. } \\
\text { Granger causality test } \\
\text { to GDP and from } \\
\text { indicates there is no } \\
\text { unidirectional } \\
\text { evidence of a causal } \\
\text { relationship with } \\
\text { Minimum wage and } \\
\text { evidence }\end{array}$ \\
\hline
\end{tabular}




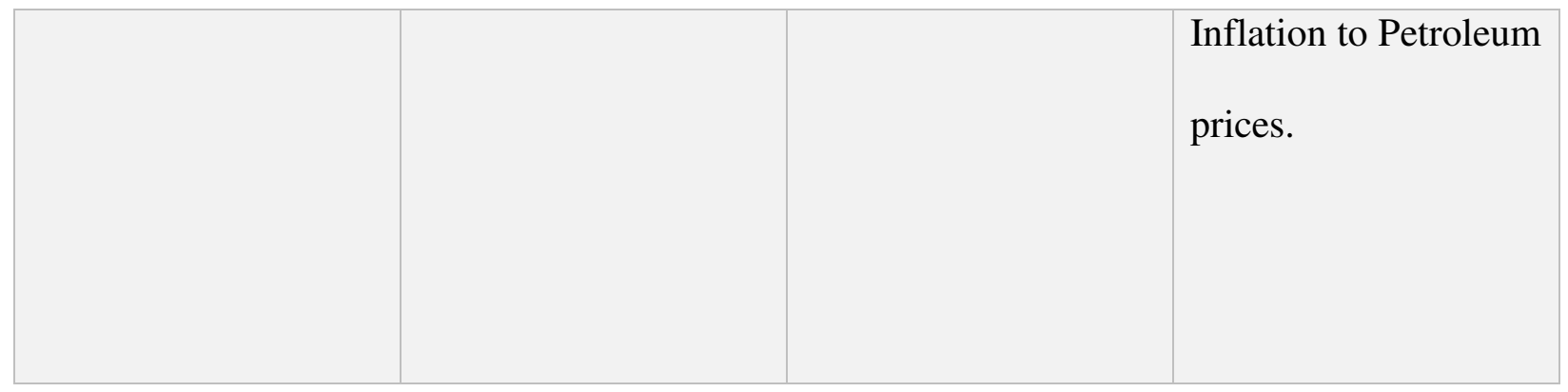

In summary, concepts, theory and empirical literature on relationship between petroleum fuel price fluctuation and performance of macro economy of emerging and developing countries especially oil producing countries such as Nigeria and others has been reviewed. One such area that has attracted recent research focus is deregulation of the downstream oil sector which many researchers like Akinola (2011) argue subsidy removal will reveal true cost of petroleum-energy consumption and thereby results in higher efficiency through competition whilst others like Nwosu (2009), in his study impact of fuel prices on inflation concludes subsidy should be maintain to shield the economy from adverse oil price hike. However most of this work has look at either pre deregulation era or many years of post-deregulation era but a research on a young deregulated downstream sector like 16 months old as in the case of Ghana is missing irrespective how findings from such work can easily inform quick policy direction to avoid prolong adverse impact from regulation of the downstream petroleum sector. This research seems to provide such a tool to deal with such situation.

Again many literature work on impact of petroleum product prices(as well as deregulation) on economic growth indicators such as inflation especially in sub-sahara Africa have adopted either 
OLS or VAR model and has also considered either annual or quarterly data. This thesis apply ARDL model on monthly data to study the petroleum product prices as well as deregulation on inflation in Ghana. This thesis is the first study on deregulation in Ghana using ADRL model and hence will fill methodology research gap of deregulation and inflation study in Ghana and also in a wider scope.

\section{Methodology}

\subsection{Introduction}

The method to be used for estimation and analyses of exploring deregulation as a tool for socioeconomic management in the downstream sector of the Ghanaian petroleum industry is specified. In sum, this chapter provides brief description of model specification, estimation technique and the data gathering processes.

The chapter is organized around the following sections; model specification to examine the impact of oil price deregulation on Inflation, definition and Justification of the Variables, Hypotheses of the thesis and the econometric techniques used for the estimations as well as the data collection procedure.

\subsection{Model Specification}

Inflation, output (GDP), exchange rate, monetary rule, total energy production and other economic indicators are influenced by prices of petroleum products. These petroleum products are petrol 
(premium), gasoline, kerosene and liquefied petroleum gas. In order to examine the impact of oil price deregulation on Inflation, this study will consider all these parameters.

The below log -log model are specified as

INFL, = F (Pmp, Gasop, Kerp, Lpgp, $)$

$\operatorname{linfl} l_{t}=\beta_{0}+\beta_{1} \ln \mathrm{PmP}_{t}+\beta_{2} \operatorname{lnIGasOP_{t}}+\beta_{3} \ln \mathrm{KerP}_{t}+\beta_{4} \ln \operatorname{Lpgp}_{t}+\varepsilon_{t}$

where the $\beta s$ are the parameters to be estimated, et represents the error term, infl $l_{t}$ inflation rate , $\ln \mathrm{PmP}_{t}$ is ex premium pump price $\mathrm{P}, \mathrm{GasOP}_{t}$ gasoline pump price, $\mathrm{KerP}_{t}$ kerosene pump price, $\operatorname{Lpg}_{t} \operatorname{Lpg}$ pump price and $\ln$ is the natural logarithmic operator

\subsection{Data Sources}

The thesis makes extensive use of secondary data since it is accurate for the analysis and readily available, thus making it convenient to use (Ghauri, et al., 2002).Thus the study employs annual time series data from Africa Development Indicators on the variables of, exchange rate (proxied using GHC to US\$), Inflation (CPI-overall) and Monetary policy rule will be obtained from Bank of Ghana annual time series publications. The monthly time series data used are from the period of January 2000 to October 2016. Thus total sample size is 191 months. Data on the deregulated petroleum prices is obtained from the National Petroleum Authority (NPA) ex-pump two-week inventory window $\left(1^{\text {st }}-16^{\text {th }}\right.$ of every month $)$ indicative price publications from June, 2015 to date. 


\subsection{Econometric Techniques for Estimation}

\subsubsection{Test of Unit Root}

Current standard regression analysis begins with the investigations into the stationarity of the variables that are used. The Augmented Dickey-Fuller (ADF) test is employed to determine the level or degree of integration of the variables - how many times the variables need to be differenced to attain stationarity. Thus ADF tests the equation;

In order to determine the order of integration of the series, the usual Augmented Dicky-Fuller (ADF) unit root tests are carried out. If the variables in the model are non-stationary, it will end up with spurious regression and the test statistics become asymptotically non normal. Even if, bound testing does not require pretesting for a unit root, in the case of I (2) variables, the computed Fstatistic for the existence of co-integration is not valid (Pesaran et al, 2001). Bound testing premise from assumptions of mixture of I (0), I (1) variable.

The ADF test can be given by

$$
\Delta y_{t}=\mu+\gamma t+\beta y_{t-1}+\sum_{i=1}^{k} \lambda_{i} \Delta y_{t-1}+u_{t}
$$

Where, ${ }^{y_{t}}$ is the variable of interest, $\mathrm{t}$ is the time trend, $\mathrm{k}$ is the maximal lag length, ${ }_{t}$ is the white noise error term.

Equation (3) is applied to all variables. Hypothesis to be tested is as follows:

Hypothesis to be tested is as follows:

$\mathrm{H}_{0}: \beta_{1}=0=\beta_{2}=0=\beta_{N}=0$ 
$\mathrm{H}_{1}: \beta_{1} \neq 0 \neq \beta_{2} \neq 0 \neq \beta_{N} \neq$ or $=0$

In the context of the ADF test, if the calculated ADF test statistic is greater than the MacKinnon critical values, the null hypothesis $\left(\mathrm{H}_{\mathrm{O}}\right)$ is rejected which implies that the variable under consideration is stationary and integrated of order zero, that is, $\mathrm{I}(0)$ otherwise accept $\mathrm{H}_{\mathrm{O}}$ which implies that the series in question is not stationary (Gujarati, 2004).

Breusch-Pagan-Godfrey test are also carried out to ascertain presence or absence of any serial correlation and heteroscedasticity in the errors $\left(\mu_{t}\right)$ or the residuals.

\subsubsection{Test of Cointegration}

Since the variables to be used are all not likely to be stationary, applying OLS on the level variables will produce spurious result as noted by Granger and Newbold (1974).

ARDL bound test is used to test for co integration among the variables when they are integrated of different order less than I (2). When the test for stationarity gives I(0) non stationarity then OLS is appropriate to use and if all variables are non-stationary I(1) or I(2) then $\operatorname{VECM}(\mathrm{Johnson}$ approach) is much simple model to use. Since the unit root(ADF) test of this model were a mixture of both I(0) and I(1) and no I(2), ARDL bound test approach was adopted for the test for cointegration. The F statistic value must be greater than the upper bound of the chosen significance level to conclude presence cointegration or long equilibrium. When cointegration is established then the ARDL cointegration model for both short run and long run is estimated. The next chapter discusses in detail the lag selection criteria for the cointegration test as well.

\subsubsection{Autoregressive-Distributed Lag (ARDL) model}


Due to the dynamic nature of the study variables being of a short observation period, this study employs this model on the monthly data over the period January 2000 to October 2016, examine the effect of deregulation of downstream oil sector on the macroeconomic variables of Inflation (CPI). The study employs ARDL model unlike most other studies such as Arenze (2011), Bobai (2012), Monday (2013), Sani (2013) etc.

who used OLS and VAR with annual data, because the monthly data of this study present a problem of non stationarity of which after differencing gives mix orders i.e. both $\mathrm{I}(0)$ and $\mathrm{I}(1)$ and hence neither OLS or VAR, or VEC is appropriate but ARDL. Also most literature work on deregulation or fuel prices change impact on macroeconomic variable such as inflation, GDP etc. have used annual data with VAR, VECM and OLS and hence this will also fill literature gap of methodology or model for analysis.

According Pesaran and Pesaran (1997), one merit of ARDL modelling is that, it is less rigid, and can be employed on variables with different integration orders. In addition, the ARDL approach modelling can take sufficient lags in capturing the relationship among the time series data (Laurenceson and Chai, 2003). More so, according to Banerjee et al., (1993), one can derive an error correction term (ECT) via simple linear transformation. Laurenceson and Chai (2003), explains that, ARDL modelling helps to capture both short-run and long-run relationships, and helps evade stationarity problems with time series data.

The study specify the model for examining oil-price deregulation effect on inflation relationship using the ARDL model specification of Pesaran et al., (2001), which can be employed whether the variables are integrated of order zero or one (i.e., $\mathrm{I}(0)$ or $(\mathrm{I}(1))$, as follows; 


$$
Y_{t}=\beta_{1, i}+\sum_{i=1}^{n} \beta_{2, i} Y_{t-i}+\sum_{i=1}^{n} \beta_{3, i} X+\sum_{i=1}^{n} \beta_{4, i} D_{i}+\pi_{2} E C T_{t-i}+\varepsilon_{t}
$$

Where

$\mathrm{Y}=\mathrm{A}$ vector of the Explanatory variable, inflation.

$\mathrm{X}=$ vector of the explanatory variable, which includes the variable of past inflation, exchange rate, and monetary policy rule.

$\mathrm{D}=$ exogenous dummy variables for oil-price deregulation

Where $\mathrm{D}=1$, for years after oil-price deregulation

$$
\mathrm{D}=0 \text {, if otherwise. }
$$

$\mathrm{ECT}=$ error correction term,

$\varepsilon_{t}=$ residual error term, and

And $t$ is time script

\subsubsection{Passing-Through International Prices}

The model of Pass- through is to determine the extent to which Price variation in the world or international market affects the domestic consumer. This takes into account the Price of domestic Petroleum Product as against that of international Price in domestic currency so as to incorporate the effect of exchange rate and Price change. According to Baig et al (2007), the Pass through is calculated as below.

pass - through $\frac{\mathbf{P}_{\text {DOMESTIC, 2016 }}-\mathbf{P}_{\text {DOMESTIC,2000 }}}{\mathbf{P}_{\text {WORLD }, 2016}-\mathbf{P}, \text { WORLD 2016 }}$

pre deregulation era pass - through $\frac{\mathbf{P}_{\text {DOMESTIC,MAY 2015 }}-\mathbf{P}_{\text {DOMESTIC,JAN } 2000}}{\mathbf{P}_{\text {WORLD,MAY 2015 }}-\mathbf{P}, \text { WORLD JAN } 2016}$ 
Post deregulation era pass - through $\frac{\mathbf{P}_{\text {DOMESTIC,AUG 2016 }}-\mathbf{P}_{\text {DOMESTIC,JUN } 2015}}{\mathbf{P}_{\text {WORLD,AUG 2016 }}-\mathbf{P}, \text { WORLD JUN } 2015}$

$\mathbf{P}_{\text {DOMESTIC,2016 }}$ Represent price of fuel in domestic market in domestic currency whiles $\mathbf{P}_{\text {WORLD,AUG } 2016}$ represent Price of the fuel in world market in domestic currency. The equation represents change in prices between last month of the survey period and that of initial survey month. Since this study looks at deregulation, it will evaluate the pass through in pre deregulated era and post deregulated era as indicated by the equations 6 and 7 above.

Since Ghana is net importer of crude oil, the FOB regional price is used such as that of Rotterdam.

\section{Discussion}

Table 2 gives the summary statistics of the variables used for the empirical analysis using their natural logarithmic forms. The measure of central tendency was done by the use of the Means and the medians of the variables. Over the period under study. The measure of dispersion was also captured with the use of standard deviations; all the variables are not widely dispersed about their mean values. 
Table 2 A Summary of Descriptive Statistics

\begin{tabular}{|c|c|c|c|c|c|c|}
\hline & $\begin{array}{l}\text { LOGINF } \\
\text { L }\end{array}$ & LOGASO & LOGER & $\begin{array}{l}\text { LOGKER } \\
\text { P }\end{array}$ & LOGLPG & $\begin{array}{l}\text { LOGPM } \\
\text { P }\end{array}$ \\
\hline Mean & 1.194079 & - $\quad 0.091335$ & 0.091417 & -0.165828 & -0.124763 & 1.080988 \\
\hline Median & 1.204120 & -0.064493 & -0.008885 & -0.063235 & -0.097888 & 0.798200 \\
\hline Maximum & 1.622214 & 0.565451 & 0.662758 & 0.512551 & 0.551266 & 3.558489 \\
\hline Minimum & 0.924279 & -0.958607 & -0.468521 & -0.958607 & -0.853872 & 0.140000 \\
\hline Std. Dev. & 0.176788 & 0.419651 & 0.260608 & 0.383585 & 0.380329 & 0.937134 \\
\hline Skewness & 0.504733 & -0.370818 & 0.423373 & -0.119926 & 0.044640 & 1.216706 \\
\hline Kurtosis & 2.672427 & 2.117037 & 2.837648 & 2.425333 & 2.066287 & 3.247958 \\
\hline $\begin{array}{l}\text { Jarque- } \\
\text { Bera }\end{array}$ & 9.339106 & 11.02498 & 6.163515 & 3.215268 & 7.294932 & 49.60887 \\
\hline Probability & 0.009376 & 0.004036 & 0.045879 & 0.200361 & 0.026057 & 0.000000 \\
\hline Sum & 237.6217 & -18.17557 & 18.19197 & -32.99969 & -24.82776 & 215.1167 \\
\hline $\begin{array}{l}\text { Sum } \\
\text { Dev. }\end{array}$ & 6.188293 & 34.86918 & 13.44746 & 29.13323 & 28.64075 & 173.8876 \\
\hline
\end{tabular}

Source: Author's Estimation, 2016

\subsection{Graphical Analysis}

Below is the graphical analysis which shows the trends of inflation, Inflation, exchange rate, Kerosene price, gasoline price, liquefied petroleum gas price, and premium mix petrol price from the period January 2000 to July2016 in natural form 
4.3.1 Trend Analysis of Variables in Their Log Form

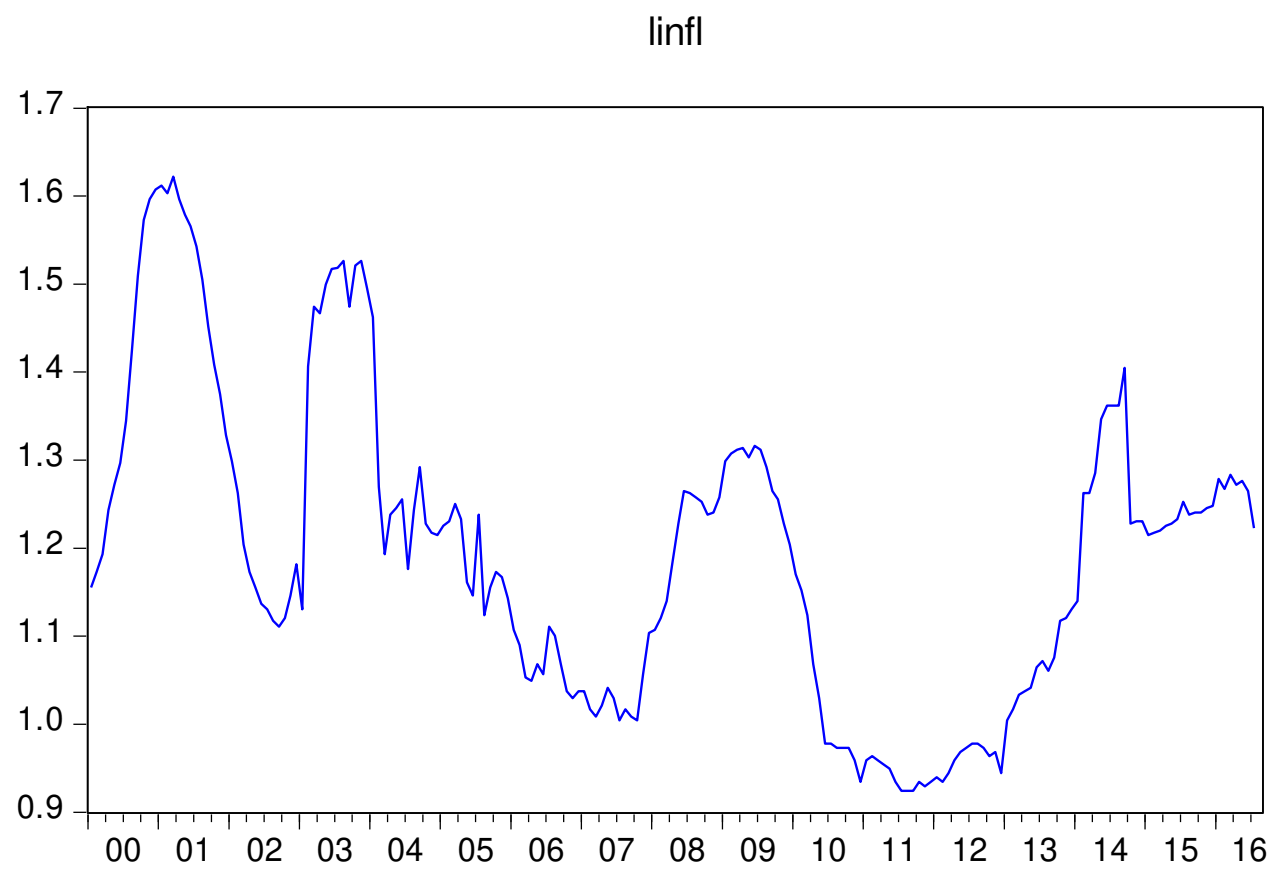

Figure 1: A Graph of Inflation (2000 to 2016) 


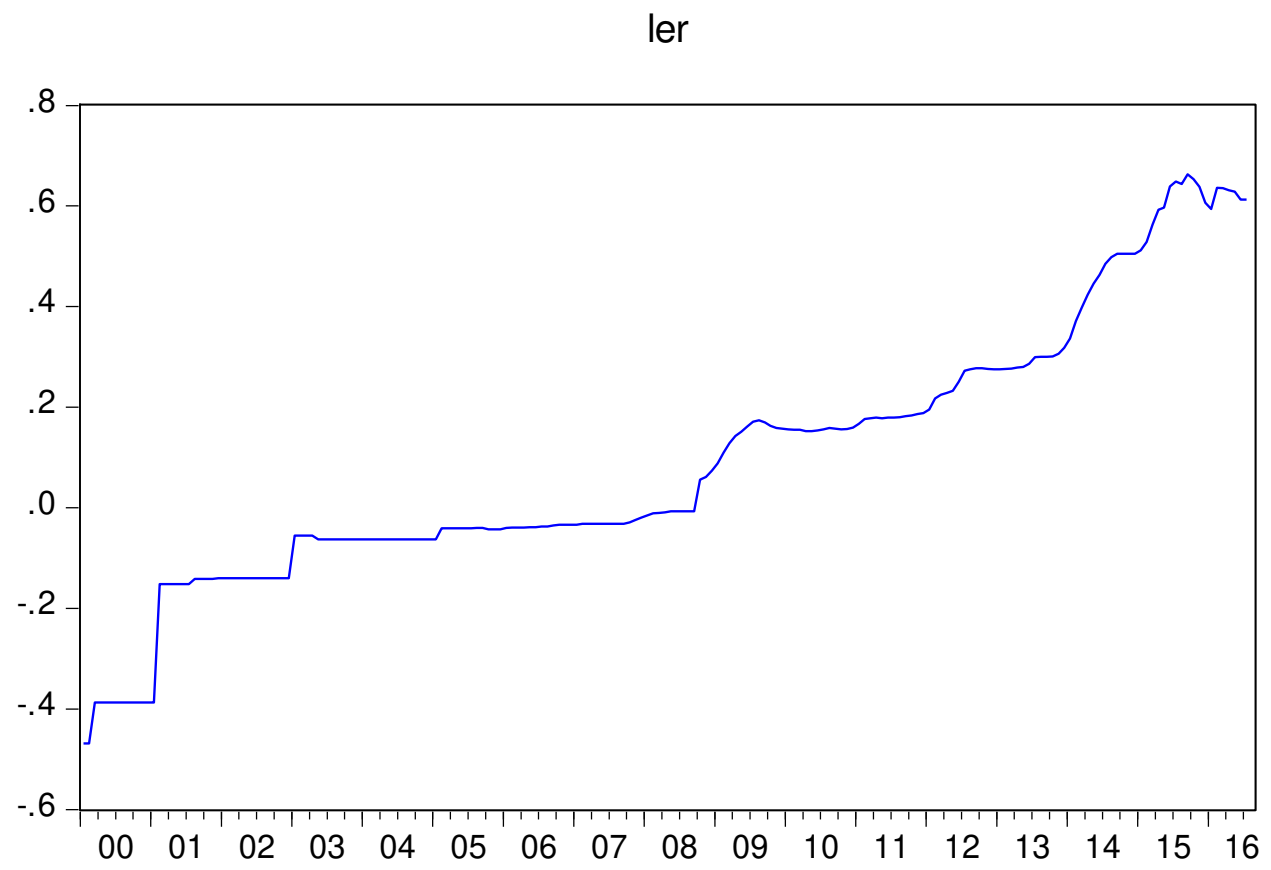

Figure 2: A Graph of Exchange rate (2000 to 2016)

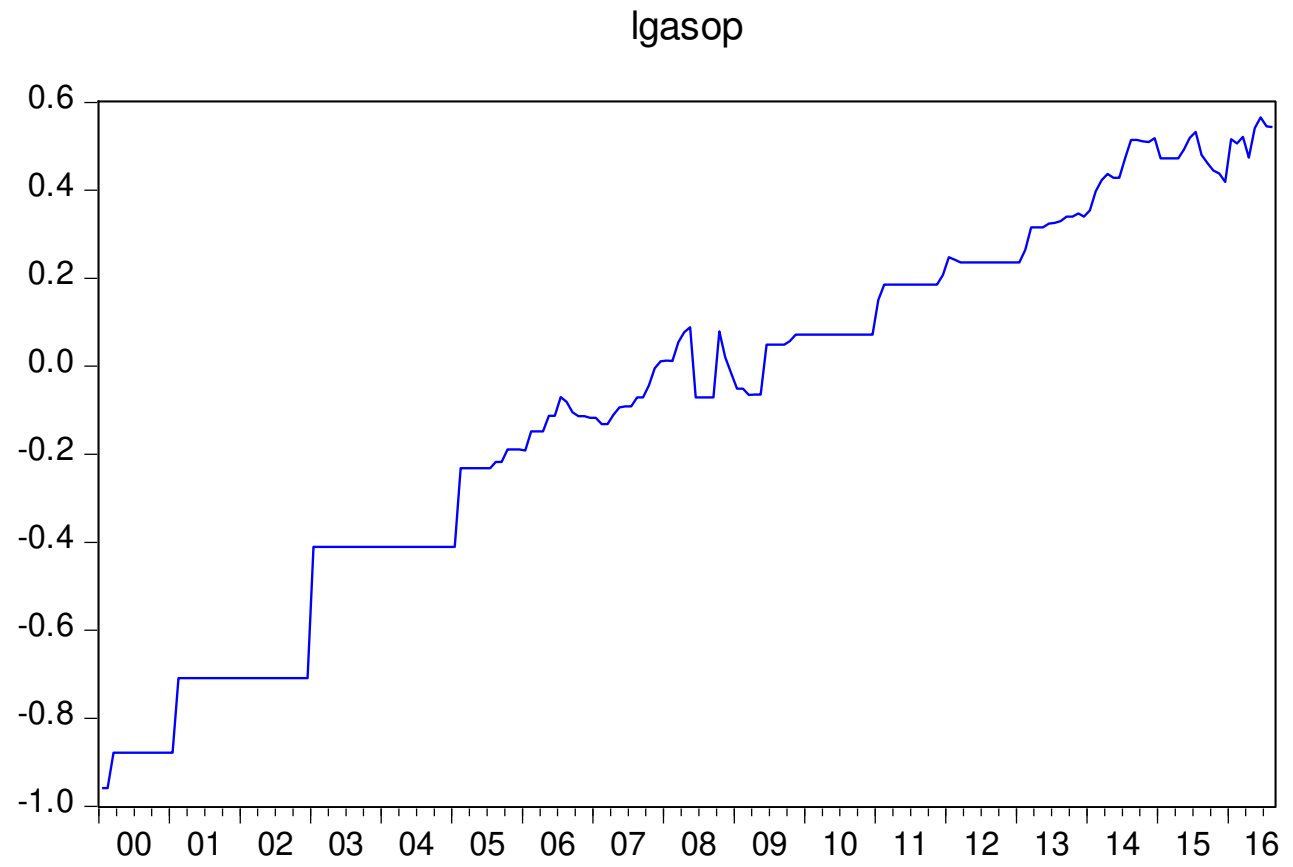

Figure 3: A Graph of gasoline price (2000 to 2016) 
Ikerp

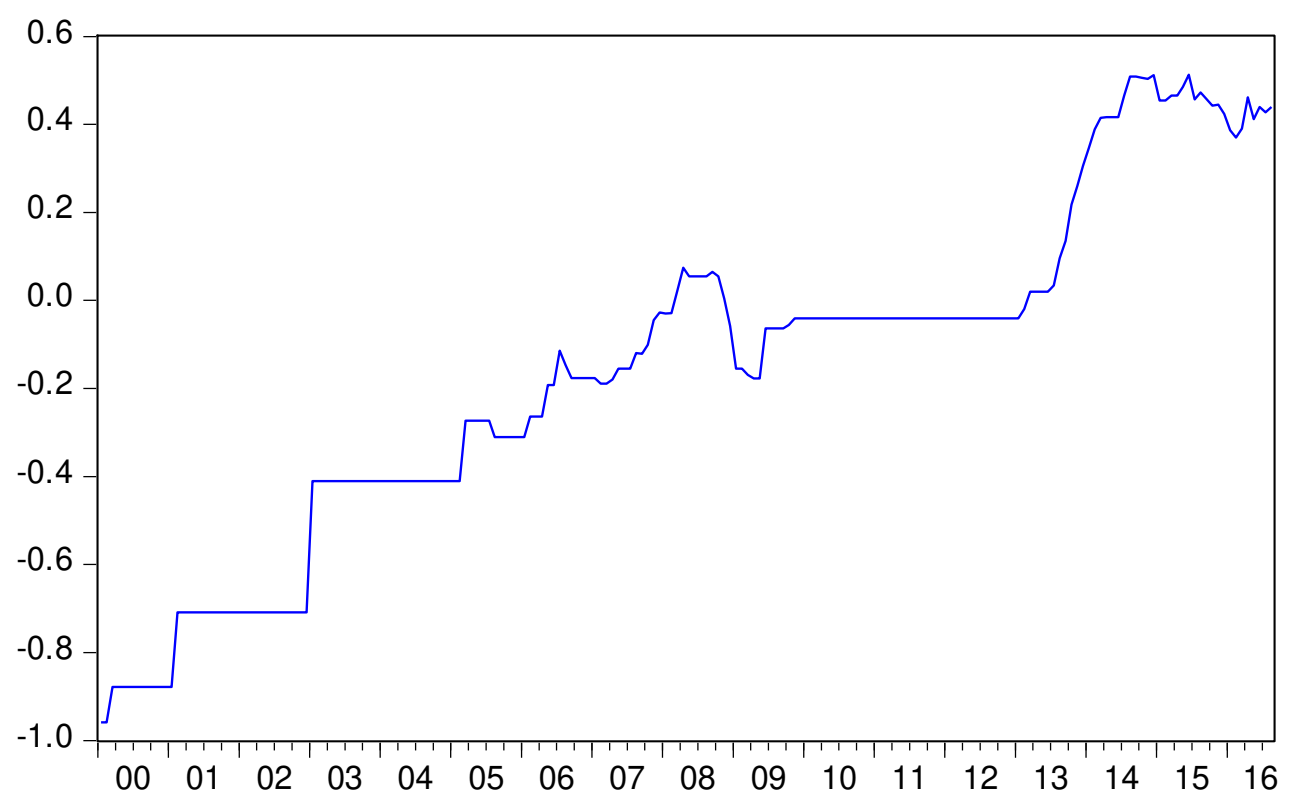

Figure 4: A Graph of kerosene price (2000 to 2016) 
Ilpg

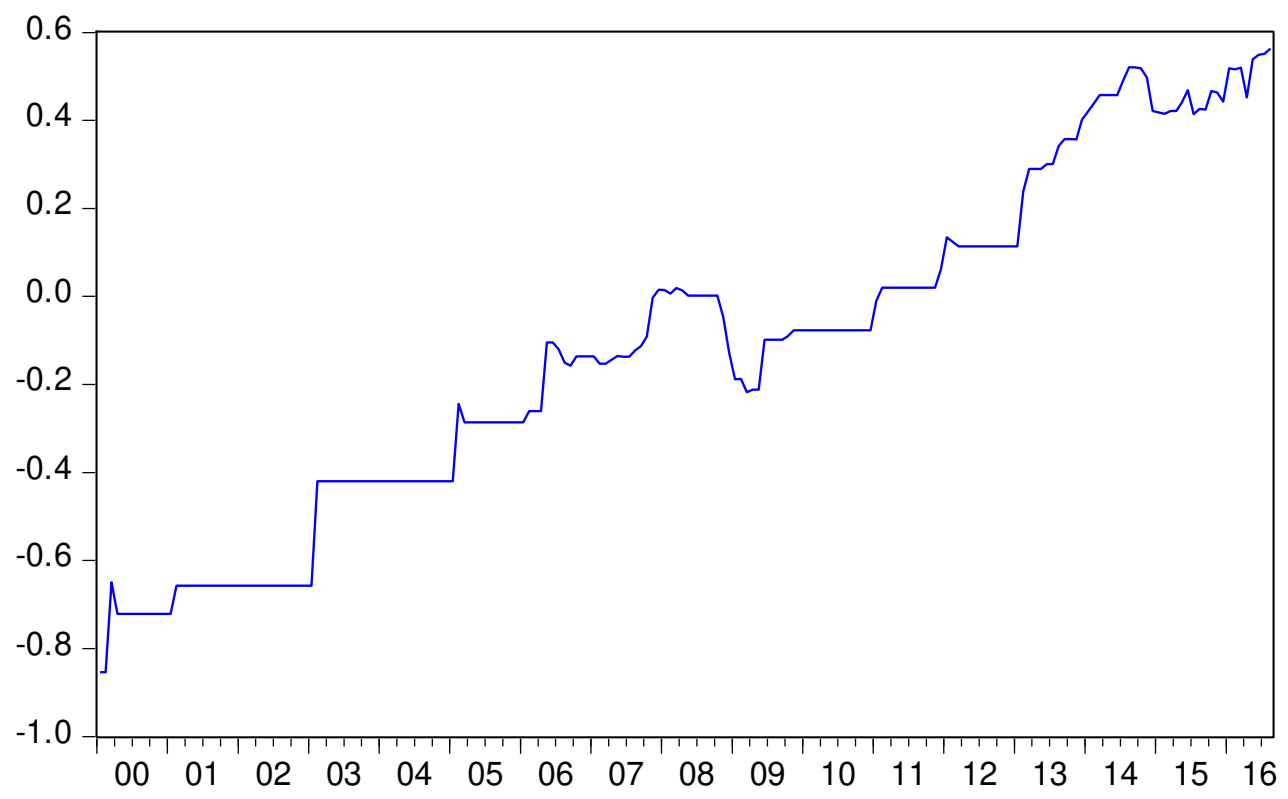

Figure 5: A Graph of LPG price (2000 to 2016)

Ipmp

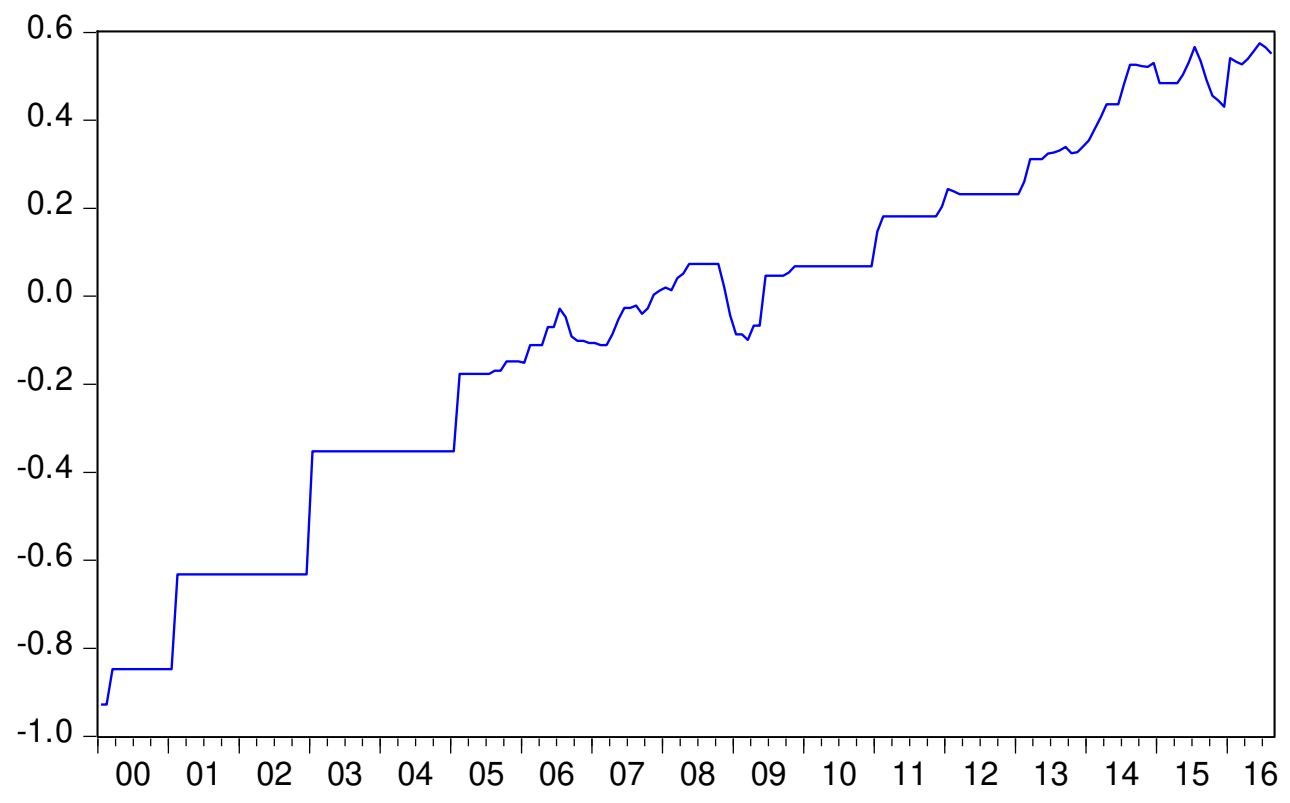

Figure 6: A Graph of Premium price (2000 to 2016) 


\subsection{Unit Root Test}

Both ADF test are employed to check for unit root based on the hypothesis below;

Null Hypothesis $\left(H_{0}\right)$ : Has a unit root

Alternative Hypothesis $\left(H_{1}\right)$ : Has no unit root

Table 3 ADF Unit root test results

$\mathrm{ADF}$ unit root test

\begin{tabular}{|c|c|c|c|c|c|c|c|}
\hline Variable & $\begin{array}{l}\text { Determinis } \\
\text { tic Term }\end{array}$ & $\begin{array}{l}\text { Test } \\
\text { Statistic } \\
\text { Value @ } \\
\text { level }\end{array}$ & $\begin{array}{l}5 \% \\
\text { Critical } \\
\text { Value @ } \\
\text { level }\end{array}$ & $\begin{array}{l}\text { Test } \\
\text { Statistic } \\
\text { Value @ } \\
\mathbf{1}^{\text {st }} \\
\text { difference }\end{array}$ & $\begin{array}{l}5 \% \\
\text { Critical } \\
\text { Value @ } \\
1^{\text {st }} \\
\text { difference }\end{array}$ & $\begin{array}{l}\text { Test } \\
\text { Statistic } \\
\text { Value @ } \\
2^{\text {nd }} \\
\text { difference }\end{array}$ & $\begin{array}{l}5 \% \\
\text { Critical } \\
\text { Value @ } \\
2^{\text {nd }} \\
\text { difference }\end{array}$ \\
\hline LINF & $\begin{array}{l}\text { Constant } \\
\text { and trend }\end{array}$ & -1.835036 & -3.432682 & -11.72268 & -3.432799 & & \\
\hline $\begin{array}{l}\text { LGASO } \\
\text { P }\end{array}$ & $\begin{array}{l}\text { Constant } \\
\text { and trend }\end{array}$ & -3.529771 & -3.432566 & & & & \\
\hline LER & $\begin{array}{l}\text { Constant } \\
\text { and trend }\end{array}$ & -2.165015 & -3.432799 & -13.27590 & -3.432799 & & \\
\hline
\end{tabular}




\begin{tabular}{|l|l|l|l|l|l|l|l|}
\hline LKER & $\begin{array}{l}\text { Constant } \\
\text { and trend }\end{array}$ & -2.332644 & -3.432566 & -13.03956 & -3.432682 & & \\
\hline LLPG & $\begin{array}{l}\text { Constant } \\
\text { and trend }\end{array}$ & -3.157017 & -3.432566 & -14.62764 & -3.432682 & & \\
\hline LPMP & $\begin{array}{l}\text { Constant \& } \\
\text { Trend }\end{array}$ & -3.342390 & -3.432566 & -13.55204 & -3.432682 & & \\
\hline
\end{tabular}

Source: Author‘s Estimation, 2016

Considering the results of the ADF unit root test, all variables except lgasop were not stationary at level and hence have unit root in them requiring differencing. They became stationary at first difference and hence presence of both I (0) and I (1) which makes necessity of cointegration test and also ARDL an appropriate model for the short and long run test.

\subsection{Lag Length Selection Test}

Before estimating an ARDL model, it is important to determine the optimal lag length of the model to ensure that the parameters are consistent. Each of the information criteria, as per the table below, suggests the various lag length. Maximum lag length $m$ was chosen (usually 1 for annual data, 4 for quarterly and 12 for monthly time series data. VAR model in level was run for lag lengths of 1...9. The AIC: Akaike information criterion and SC: Schwarz information criterion was selected and lags length that minimizes them was selected. Due to first deference of the variables, the minimum AIC corresponding lag length of two (2) was selected against minimum SC of lag length one (1) for the optimal selection criteria. Confirmation test for appropriateness of 
the AIC was done by checking for autocorrelation which was positively confirmed since there was no autocorrelation of the residuals and hence correct lag length of two(2).

A test for cointegration between our independent variables and inflation using the ADRL bound test cointegration approach was conducted as that approach is not sensitive to what is chosen as the endogenous variable.

\subsection{Cointegration Analysis}

All the variables at levels are non-stationary except lgasop. The possibility of the presence of cointegrating relations among the variables is been indicated. Cointegration analysis shows the long- run steady state relations among non-stationary integrated variables; therefore, it is a necessary step to build empirically meaningful relationships. Hence cointegration analysis test is been conducted for the existence of long run relationship based on the hypothesis below;

Null Hypothesis $\left(\mathrm{H}_{0}\right)$ : No cointegration or long run relationship among variables

Alternative Hypothesis $\left(\mathrm{H}_{1}\right)$ : Cointegration relationship among variables

Summary of ARDL bound test for cointegration is shown in the table $4.4 \mathrm{a}$ and $4.4 \mathrm{~b}$ below

ARDL Bounds Test

Null Hypothesis: No long-run relationships exist among variables 
Table 5a test statistics

\begin{tabular}{lll}
\hline \hline Test Statistic & Value & $\mathrm{K}$ \\
\hline \hline F-statistic & 4.204281 & 6 \\
\hline \hline
\end{tabular}

Table 5b Critical Value Bounds

\begin{tabular}{lll}
\hline \hline Significance & I0 Bound & I1 Bound \\
\hline \hline $10 \%$ & 2.12 & 3.23 \\
$5 \%$ & 2.45 & 3.61 \\
$2.5 \%$ & 2.75 & 3.99 \\
$1 \%$ & 3.15 & 4.43 \\
\hline \hline
\end{tabular}

Source: Author's Estimation, 2016

The F statistic indicates a value greater than both the lower and upper bound values at $5 \%$ critical value, therefore the test rejects the null hypothesis of no cointegration between inflation and the dependent variables and hence there is cointegration.

Table 5c ARDL Cointegrating short run coefficient

\begin{tabular}{lllll}
\hline \multicolumn{1}{l}{ Cointegrating Form } & & & \\
\hline \hline Variable & \multicolumn{1}{l}{ Coefficient Std. Error } & t-Statistic & Prob. \\
\hline \hline D(LINFL(-1)) & 0.132185 & 0.066577 & 1.985432 & 0.0486 \\
D(LGASOP) & 0.168780 & 0.097694 & 1.727648 & 0.0857 \\
D(LKERP) & 0.098583 & 0.042090 & 2.342198 & 0.0202 \\
D(LLPG) & 0.320183 & 0.083848 & 3.818631 & 0.0002 \\
D(LPMP) & -0.427915 & 0.133395 & -3.207880 & 0.0016 \\
D(LPMP(-1)) & 0.380873 & 0.078002 & 4.882845 & 0.0000
\end{tabular}




\begin{tabular}{lllll}
$\mathrm{D}($ LER $)$ & -0.008906 & 0.038741 & -0.229894 & 0.8184 \\
$\mathrm{D}(\mathrm{DU})$ & 0.007592 & 0.014205 & 0.534477 & 0.5937 \\
CointEq(-1) & -0.068794 & 0.022501 & -3.057426 & 0.0026 \\
\hline \hline
\end{tabular}

The above results show the lag of inflation $\left(1^{\text {st }}\right.$ lag $)$, kerosene price, premium price, $\operatorname{lag}\left(1^{\text {st }}\right.$ lag $)$ of premium price, lpg price, impacts inflation and aside premium price which impact negatively, the above product prices influences inflation positively(increase as inflation increases).these were also seen as significant at $5 \%$ level.

The coefficient of the short run independent variables is the elasticities that explain the extent of their impact on inflation. For example a unit change of premium price (increase) will lead to a decrease in inflation by $42 \%$ whilst that of kerosene will lead to an increase of $9.8 \%$ and that of LPG will lead to an increase of $32 \%$ inflation by its change of $1 \%$.(change). The dummy for accounting for deregulation effect showed not significant in explaining inflation change.

The coefficient of the cointegration was also found to be negative and significant.

Table 5d ARDL Long Run Coefficients

\begin{tabular}{lllll}
\hline \hline Variable & \multicolumn{2}{c}{ Coefficient Std. Error } & t-Statistic & Prob. \\
\hline \hline LGASOP & 2.453399 & 1.769426 & 1.386551 & 0.1672 \\
LKERP & 1.433007 & 0.598195 & 2.395553 & 0.0176 \\
LLPG & 1.647374 & 0.800616 & 2.057633 & 0.0410 \\
LPMP & -5.632792 & 2.305224 & -2.443490 & 0.0155 \\
LER & -0.129463 & 0.582564 & -0.222229 & 0.8244
\end{tabular}



DU
$\begin{array}{llll}0.110360 & 0.212004 & 0.520557 & 0.6033\end{array}$
$\mathrm{C}$
$\begin{array}{llll}1.454213 & 0.141575 & 10.271671 & 0.0000\end{array}$

The above results indicates that in the long run as inflation increases price of kerosene, liquefied petroleum gas and all price of the petroleum product (after deregulation) also increases whilst inflation decreases with premium prices and exchange rate increase. However the $t$ statistics showed only significance for kerosene price, liquefied petroleum gas price and premium price (only negative coefficient) at the $5 \% \mathrm{p}$ value. The result for the fuel prices after deregulation was not significant and hence no significant change of their impact after the deregulation.

Table 5 Diagnostic test results of the residuals

Heteroskedasticity Test: Breusch-Pagan-Godfrey

\begin{tabular}{lrll}
\hline \hline F-statistic & 1.495855 & Prob. F(11,185) & 0.1359 \\
Obs*R-squared & 16.09058 & Prob. Chi-Square(11) & 0.1378 \\
Scaled explained SS 57.31174 & Prob. Chi-Square(11) & 0.0000 \\
\hline \hline
\end{tabular}

Table 6 Breusch-Godfrey Serial Correlation LM Test:

\begin{tabular}{llll}
\hline \hline F-statistic & 0.264416 & Prob. F(2,183) & 0.7679
\end{tabular}


Obs*R-squared $\quad 0.567650 \quad$ Prob. Chi-Square(2) 0.7529

The diagnostic tests on residuals are used to check the validity of the model. For checking that the variance of the residual is homoscedastic or heteroscedastic, the Breusch-Pagan Heteroskedasticity Test was applied on the regression model. Null hypothesis is given by $\mathrm{H}_{0}$ : there is homoscedasticity .The F-Statistic was 1.495855 with P-value of 0.1359 or chi square of P-value of 0.1378 at $5 \%$ and hence the test do not reject the Null hypothesis which concludes absence of heteroskedasticity.

Also, the Breusch-Godfrey Serial Correlation LM test statistic was 0.264416 with P-value of 0.7679 which shows that the residuals are not serially correlated since it did not reject Null hypothesis of no serial correlation.

\subsection{Granger Causality Test}

To identify if the independent variables in the short run could influence inflation in the Ghanaian economy. The two null hypothesis and Alternative hypothesis below were used; i.e. pairwise

Null Hypothesis $\left(H_{0}\right) 1$ : independent does not variable granger cause INFL

Null Hypothesis $\left(H_{0}\right) 2$ : INFL do not granger cause independent variable

Alternative Hypothesis $\left(H_{1}\right) 1$ : independent variables granger cause INFL

Alternative Hypothesis $\left(H_{l}\right) 2$ : INFL granger cause independent variables

This result is shown in the table below by conducting a granger causality test. 
Table 7: Granger causality test

\begin{tabular}{|lll|}
\hline Null Hypothesis 1 & F Statistics & Probability \\
\hline LGASOP does not Granger Cause LINFL & 7.5503 & 0.000008 \\
\hline LERP does not Granger Cause LINFL & 7.6836 & 0.0006 \\
\hline LKERP does not Granger Cause LINFL & 13.7544 & 0.000003 \\
\hline LLPGP does not Granger Cause LINFL & 0.67662 & 0.5095 \\
\hline LPMP does not Granger Cause LINFL & 13.1425 & 0.000004 \\
\hline DU does not Granger Cause LINFL & & \\
\hline Null Hypothesis 2 & 0.12533 & 0.8823 \\
\hline & & \\
\hline & & \\
\hline
\end{tabular}




\begin{tabular}{|lll|}
\hline LINFL does not Granger Cause LGASOP & 0.49325 & 0.6114 \\
\hline LINFL does not Granger Cause LERP & 1.56193 & 0.2125 \\
\hline LINFL does not Granger Cause LKERP & 0.59980 & 0.5723 \\
\hline LINFL does not Granger Cause LLPGP & 0.9064 & 0.4057 \\
\hline LINFL does not Granger Cause LPMP & 0.6426 & 0.5071 \\
\hline LINFL does not Granger Cause DU & 0.02337 & 0.9769 \\
\hline
\end{tabular}

From the table 7 above, the $\mathrm{F}$ statistic has $\mathrm{F}$ value greater than 3.84 except logarithm of ; liquefied petroleum gas price ( 0.67662$)$ and associated probabilities values of the causality test indicate significance and hence are enough to reject the null hypothesis 1 , which implies aside except logarithm of ; liquefied petroleum gas price, the rest of petroleum products prices as well as exchange rate granger cause inflation. This further means the past values of logarithm of ; gasoline price, exchange rate, kerosene price and premium petrol price significantly contribute to the Prediction of current inflation According to the F statistics for the null hypothesis 2 causality runs unidirectional from logarithm of ; gasoline price , exchange rate,, kerosene price and premium petrol price to inflation. Thus aside LPG Price, the rest of petroleum products prices as well as 
exchange rate causes inflation in the long run and can stire movement in inflation. It is also evident from table 4.7 that feedback relationship exists between logarithm of; gasoline price, exchange rate, kerosene price, premium petrol price and inflation in Ghana over the period January 2000August 2016.

The inclusion of the dummy was to discover whether the deregulation also caused any change in the direction or nature of the causality. F value of $0.12533<3.84$ for the dummy(DU) allow us not to reject the null hypothesis and hence DU or after deregulation no change was observed for the independent variables causality with inflation confirming both the short and long run not significance for the deregulation.

4.8 Estimation of PASS $-\quad$ THROUGH $\frac{\mathbf{P}_{\text {DoMESTIC,OCT 2016 }}-\mathbf{P}_{\text {DOMESTIC,JAN } 2000}}{\mathbf{P}_{\text {WORLD,OCT 2016 }}-\mathbf{P}_{\text {,WORLD JAN } 2016}}$

Table 8 Results for Pass through calculations

Fuel Product

Pre deregulation Era

Pass through ratio
Gasoline
0.416
$-0.069$

Post deregulation Era

Pass through ratio

Kerosene $0.48 \quad 0.2$

\section{LPG}

0. 053

$-0.0199$ 
The table above shows the pass through results or ratio for gasoline $(0.416), \operatorname{kerosene}(0.48)$ and liquefied petroleum gas(-0. 069) and gasoline(0.416), kerosene(0.2) and liquefied petroleum gas(0. 0199) for pre and post deregulation era in Ghana (within year 2000 and 2016) respectively. The pass through ratio less than 1 indicates increase in international price of fuel is not fully or is less than fully pass on domestic retail fuel prices. Therefore both pre and post deregulation era recorded less than half fully passed through indicating possible government intervention through subsidy to absorb the increased price in the international market or increased competition in the post deregulation era that led to relatively lower prices. But the case of the post deregulation era indicates lower pass through ratio for all the fuels examined which shows that the deregulation has led to lower pass-through. One mjor reason for this trend is the price collapse after the implementation of the deregulation in mid 2015. Again among the fuels gasoline rated highest pass through followed by kerosene and finally lowest for LPG. 


\subsection{Conclusion and Policy Recommendations}

By estimating inflation with monthly data the period 2000-2016 the results found showed a long relationship between logarithm of; kerosene price, premium petrol price and liquefied petroleum gas price and inflation. When an ADF unit root test was performed on the variables they were found to be non-stationary at level except logarithm of; gasoline price

An ARDL bound cointegration test was carried out on the variables and was established that there exist long run relationship among the independent variables considered for this study and inflation.

An ARDL model was applied on this cointegrated equations and found that in the long run logarithm of ; kerosene price, premium and liquefied petroleum gas price impacted inflation whilst in the short run logarithm of ; inflation(-1), kerosene price, premium price, premium price (-1) and liquefied petroleum gas price had an impact on inflation.

Granger Causality Test was conducted to examine if the petroleum fuel prices and exchange rate does impact the Ghanaian economy in the short run. From the test, it was revealed that in the short run logarithm of; gasoline price, exchange rate, kerosene price and premium petrol price do significantly influence the Ghanaian economy under the period of study before deregulation but 
there was no significant change in terms of magnitude and direction of causality after the deregulation.

The study looks at the impact of price of petroleum fuel products on inflation in the Ghanaian economy in the pre and post deregulation era and associated direction of causality as well as the extent of pass through of high international petroleum products price to the domestic retail market. The inflationary change due to price of petroleum product change and pass through of such price increase in the international oil market to domestic retail market and hence consumers were put to motion.

Unlike what Danjuma ((2012) found in Nigeria of negative relationship of kerosene price change to inflation and positive to gasoline and premium, in terms of magnitude, the empirical results reveal that in the short run, $1 \%$ increase from the previous inflation will increases inflation by $13.22 \%, 1 \%$ increase of Kerosene price will increase inflation by $9.86 \%, 1 \%$ increase in liquefied petroleum price will increase inflation by $32.12 \%, 1 \%$ increase in premium petrol price will decrease inflation by $42.28 \%$ which is opposite to expectation and finally a $1 \%$ increase in previous petrol price is expected to rather increase inflation by $38 \%$ ( this is explain by the long run elasticity of which has a positive effect on inflation, i.e. as years past inflation will tend to rather increase with increase premium price). The period of deregulation saw no significant change.

Again the study revealed that, in the short run gasoline price, kerosene price and premium petrol price do significantly influence the Ghanaian economy (causes inflation) under the period of study before and after deregulation and the causality is unidirectional running to inflation. 
Contrary to as found by Baig et al (2007), that Ghana more than fully and nearly fully pass through gasoline and fuel respectively from 2003 to mid-2006, the study indicates less than half fully pass-through in the above fuel including Login greater retrospect, pass through analysis revealed Ghana has not pass through more than $50 \%$ of increase price of international or import petroleum product of gasoline, kerosene and LPG to the ordinary consumers in the period of the study and can be attributed to government intervention through subsidy which doesn't also exclude burden on fiscal policy or development of the country. However the post deregulation shows rather less pass through suggesting that government allowing the force of demand and supply to determine the price of the petroleum fuel product in the market is a good way of relieving ordinary consumers from high prices of fuel even when increased in international market and hence a better domestic fuel pricing mechanism than subsidized system.

The study recommends the full deregulation be allowed to continue since it absorbs the negative shock of high increase of fuel product price in international market on consumers due to is associated lower pass through ratio.

However, since international oil prices have fallen since the introduction of the deregulation, stability or mitigation funds should be created to cushion consumers when price rise.

The study once again recommends government or the National Petroleum Authority to consider allowing market forces to determine the prices of gasoline and premium price increase with minimal taxes and levies when to lessen the impact of fuel price increase on inflation whilst kerosene and liquefied petroleum gas price increase should be limited or restrain when inflation is to be cushion from petroleum fuel products hikes. 


\section{REFERENCES}

Ajayi, S. I. (1992). An economic analysis of capital flight from Nigeria (Vol. 993). World Bank Publications. 
Anand, R., Coady, D. P., Mohommad, A., Thakoor, V. J., \& Walsh, J. P. (2013). The fiscal and welfare impacts of reforming fuel subsidies in India.

Arenze, P.E. (2011): Energy consumption and Economic Growth in Nigeria. Trancampus Journal of Jorind ISSN 1596-8308.

Baig, T., A. Mati, D. Coady and J. Ntamatungiro. 2007. "Domestic Petroleum Product Prices and Subsidies: Recent Developments and Reform Strategies” IMF Working Paper No. 07/71.

Birol, F. (2010). World energy outlook 2010. International Energy Agency, 1.

Bobai, F. D. (2012). An analysis of the relationship between petroleum prices and inflation in Nigeria. International Journal of Business and Commerce, 1(12), 1-7.

CERA, I. (2014). Fueling the future with natural gas: bringing it home. Executive Summary. January.

Clements, B., Coady, D., Fabrizio, S., Gupta, S., Alleyne, T., \& Sdralevich, C. (2013). Energy Subsidy Reform: Lessons and Implications (Washington: International Monetary Fund).

Coady, D., Baig, M. T., Ntamatungiro, M. J., \& Mati, A. (2007). Domestic petroleum product prices and subsidies: Recent developments and reform strategies (No. 7-71). International Monetary Fund.

Coady, D., Gillingham, R., Ossowski, R., Piotrowski, J., Tareq, S., \& Tyson, J. (2010). Petroleum product subsidies: costly, inequitable, and rising. Washington, DC: International Monetary Fund 
Cooke E.F.A., Hague S., Cockburn J., Lahga A.E., Tiberti L., (). Estimating the impact on poverty of Ghana's fuel subsidy reforms and a mitigating response.

del Granado, F. J. A., Coady, D., \& Gillingham, R. (2012). The unequal benefits of fuel subsidies: A review of evidence for developing countries. World Development, 40(11), 2234-2248.

Doshi, Viren, and John Corrigan. '2015 Oil And Gas Trends'. Strategyand.

forthcoming, Washington DC.

Danjuma, B.F.( 2012) An Analysis of the Relationship between Petroleum Prices and Inflation in Nigeria, International Journal of Business and Commerce Vol. 1, No.12: Aug 2012[01-07] (ISSN:2225-2436)

Eregha .P.B., Mesagan E.P., Olawale O.O. (2015). Petroleum Products Prices and Inflationary Dynamics in Nigeria. Online at https://mpra.ub.uni-muenchen.de/70251/MPRA Paper No. 70251, posted 26 March 2016 10:32 UTC

Hossain, S. (2003). Taxation and pricing of petroleum products in developing countries: a framework for analysis with application to Nigeria.

Idris A. Sani. (2014). Impact of Petroleum Subsidy on SSB Performance in Nigeria. Journal of Economics and Sustainable Development. ISSN 2222-1700 (Paper) ISSN 2222-2855 (Online) .Vol.5, No.22, 2014. 
Institute for Fiscal Studies (2015) The Falling Crude Oil Prices: Mitigating the Risk; Policy Brief paper No. 1, January

International Monetary Fund, 2013, Energy Subsidy Reform: Lessons and Implications,

Laan, T. (2010). Gaining traction: the importance of transparency in accelerating the reform of fossil-fuel subsidies. Available at SSRN 1594183

Monday, J. U. Downstream Deregulation Policy and Economic Growth: A Case of Nigeria. EDITORIAL BOARD Patron, 1.

Obasi, I. N. (1999) Research Methodology in Political Science. Enugu: Academic Publishing Company.

Okafor Loretta (2012). Deregulation Of The Nigerian Downstream Oil Sector; Keeping Faith With A Global Trend. http://www.pppra-nigeria.org/articledetails.asp?ArticleID=16

Okeke, C. C. (2001) Foundations of Educational and Behavioural Research: Issues and Methodology. Enugu: Academic Publishing Company

Parikh, K. S. (2010). Report of The Expert Group on A Viable and Sustainable System of Pricing of Petroleum Products. Government of India. 
Pesaran, M. H., Shin, Y., \& Smith, R. J. (2001). Bounds testing approaches to the analysis of level relationships. Journal of applied econometrics, 16(3), 289-326.

Sani, S.B. (2013). Effect of deregulation of downstream oil sector on selected macroeconomic variables in Nigeria. Paper presented at: Business and Social Science Research Conference, Paris, 20-21 December, 2013.

Totonechi, J.(2011). Macroeconomic Theories Of Inflation, International Conference On Economics \& Finance Research.

Acheampong, T., \& Ackah, I. (2015). Petroleum Product Pricing, Deregulation and Subsidies in Ghana: Perspectives on Energy Security.Deregulation and Subsidies in Ghana: Perspectives on Energy Security (August 14, 2015).

Ajayi, S. I. (1992). An economic analysis of capital flight from Nigeria (Vol. 993). World Bank Publications.

Anand, R., Coady, D. P., Mohommad, A., Thakoor, V. J., \& Walsh, J. P. (2013). The fiscal and welfare impacts of reforming fuel subsidies in India.

Arenze, P.E. (2011). Energy consumption and Economic Growth in Nigeria. Trancampus Journal of Jorind ISSN 1596-8308.

Awuse, N.(2008). Determinants of petroleum prices in Ghana, 1985-2005.< retrived October $10,2016>$, 
Birol, F. (2010). World energy outlook 2010. International Energy Agency, 1.

Bobai, F. D. (2012). An analysis of the relationship between petroleum prices and inflation in Nigeria. International Journal of Business and Commerce, 1(12), 1-7.

CERA, I. (2014). Fueling the future with natural gas: bringing it home. Executive Summary. January.

Clements, B., Coady, D., Fabrizio, S., Gupta, S., Alleyne, T., \& Sdralevich, C. (2013). Energy Subsidy Reform: Lessons and Implications (Washington: International Monetary Fund).

Coady, D., Baig, M. T., Ntamatungiro, M. J., \& Mati, A. (2007). Domestic petroleum product prices and subsidies: Recent developments and reform strategies (No. 7-71). International Monetary Fund.

Coady, D., Gillingham, R., Ossowski, R., Piotrowski, J., Tareq, S., \& Tyson, J. (2010). Petroleum product subsidies: costly, inequitable, and rising. Washington, DC: International Monetary Fund Cooke E.F.A., Hague S., Cockburn J., Lahga A.E., Tiberti L., (). Estimating the impact on poverty of Ghana's fuel subsidy reforms and a mitigating response.

del Granado, F. J. A., Coady, D., \& Gillingham, R. (2012). The unequal benefits of fuel subsidies: A review of evidence for developing countries. World Development, 40(11), 2234-2248.

Doshi, Viren, and John Corrigan. '2015 Oil And Gas Trends'. Strategyand.

forthcoming, Washington DC. 
Danjuma, B.F.( 2012) An Analysis of the Relationship between Petroleum Prices and Inflation in Nigeria, International Journal of Business and Commerce Vol. 1, No.12: Aug 2012[01-07] (ISSN:2225-2436).

Eregha .P.B., Mesagan E.P., Olawale O.O. (2015). Petroleum Products Prices and Inflationary Dynamics in Nigeria. Online at https://mpra.ub.uni-muenchen.de/70251/MPRA Paper No. 70251, posted 26 March 2016 10:32 UTC.

Hossain, S. (2003). Taxation and pricing of petroleum products in developing countries: a framework for analysis with application to Nigeria.

Idris A. Sani. (2014). Impact of Petroleum Subsidy on SSB Performance in Nigeria. Journal of Economics and Sustainable Development. ISSN 2222-1700 (Paper) ISSN 2222-2855 (Online) .Vol.5, No.22, 2014.

Institute for Fiscal Studies (2015) The Falling Crude Oil Prices: Mitigating the Risk; Policy Brief paper No. 1, January.

International Monetary Fund, 2013, Energy Subsidy Reform: Lessons and Implications.

Laan, T. (2010). Gaining traction: the importance of transparency in accelerating the reform of fossil-fuel subsidies. Available at SSRN 1594183

Monday, J. U. Downstream Deregulation Policy and Economic Growth: A Case of Nigeria. EDITORIAL BOARD Patron, 1. 
Okafor Loretta (2012). Deregulation Of The Nigerian Downstream Oil Sector; Keeping Faith With A Global Trend. http://www.pppra-nigeria.org/articledetails.asp?ArticleID=16.

Parikh, K. S. (2010). Report of The Expert Group on A Viable and Sustainable System of Pricing of Petroleum Products. Government of India.

Pesaran, M. H., Shin, Y., \& Smith, R. J. (2001). Bounds testing approaches to the analysis of level relationships. Journal of applied econometrics, 16(3), 289-326.

Sani, S.B. (2013). Effect of deregulation of downstream oil sector on selected macroeconomic variables in Nigeria. Paper presented at: Business and Social Science Research Conference, Paris, 20-21 December, 2013.

Totonechi,J.(2011) .Macroeconomic Theories Of Inflation, International Conference On Economics \& Finance Research. 